\title{
The development of village-owned enterprises: Lessons learned from Ponggok Village
}

\section{Pengembangan Badan Usaha Milik Desa (BUMDes): Belajar dari Desa Ponggok}

\author{
Andrian Dolfriandra Huruta*, Eranus Yoga Kundhani, \& Christopher Ramaoli Manurung \\ Faculty of Economics and Business, Universitas Kristen Satya Wacana \\ Address: Jalan Diponegoro 52-60, Sidorejo, Salatiga, Central Java 50711 \\ E-mail: andrian.huruta@staff.uksw.edu*,yoga@staff.uksw.edu, \& 222014045@student.uksw.edu
}

\begin{abstract}
The Tirta Mandiri village-owned enterprises or BUMDes is one of the best village-owned enterprises in Indonesia. It has made these village-owned enterprises a learning center for others in Indonesia. Currently, Tirta Mandiri village-owned enterprises have the role of creating new business fields in Ponggok Village (Polanharjo District, Klaten Regency). This study applied a qualitative method by conducting a case study. The primary data gathered through in-depth interviews with seven key informants and two supporting informants. The secondary data collected through the business management and planning documents of the Tirta Mandiri village-owned enterprises. Tirta Mandiri village-owned enterprises have been able to develop seven business units in the form of Limited Companies (Ltd.). Their presence can increase the output, income, and labor (multiplier effect) of the Ponggok villagers. It is proven by the presence of new businesses in the community. The development of the Tirta Mandiri village-owned enterprises is inseparable from the social capital of the community as a foundation for the development of the village-owned enterprises themselves. Furthermore, community participation actualized through investments, which are a sign of the public's trust in the village-owned enterprises. Money is energy, and planning is the compass, and authority is the driver where the village takes part in realizing its autonomy. Learning from experience is one way to create sustainable village-owned enterprises.
\end{abstract}

Keywords: village-owned enterprises; village development; local; social capital; participation

\begin{abstract}
Abstrak
Badan Usaha Milik Desa atau BUMDes Tirta Mandiri merupakan salah satu BUMDes terbaik di Indonesia. Hal tersebut yang membuat BUMDes ini menjadi pusat pembelajaran bagi BUMDes lainnya di Indonesia. Saat ini, BUMDes Tirta Mandiri berperan dalam menciptakan lapangan usaha baru di Desa Ponggok (Kecamatan Polanharjo, Kabupaten Klaten). Studi ini menerapkan metode kualitatif dengan menggunakan strategi studi kasus. Data primer dikumpulkan melalui wawancara mendalam dengan tujuh informan kunci dan dua informan pendukung. Data sekunder dikumpulkan melalui dokumen manajemen dan perencanaan bisnis BUMDes Tirta Mandiri. BUMDes Tirta Mandiri sudah mampu mengembangkan tujuh unit usaha dalam bentuk Perseroan Terbatas (PT.). Kehadiran dari ketujuh entitas bisnis dalam bentuk perseroan terbatas juga mampu meningkatkan output, pendapatan dan tenaga kerja (multiplier effect) bagi masyarakat Desa Ponggok. Hal ini dibuktikan dengan hadirnya usaha-usaha baru di masyarakat. Kemajuan dari BUMDes Tirta Mandiri tidak terlepas dari adanya modal sosial dari masyarakat sebagai pondasi untuk pengembangan BUMDes. Lebih lanjut partisipasi masyarakat diaktualisasikan melalui investasi yang menjadi tanda kepercayaan masyarakat kepada BUMDes. Dengan demikian, uang sejatinya merupakan energi, perencanaan adalah kompasnya, sedangkan kewenangan adalah wahana tempat desa berkiprah dalam mewujudkan otonominya. Belajar dari pengalaman merupakan salah satu cara untuk menciptakan BUMDes yang berkelanjutan.
\end{abstract}

Kata kunci: Badan Usaha Milik Desa (BUMDes); pembangunan desa; lokal; modal sosial; partisipasi

\section{Introduction}

The presence of village autonomy suggests that each village has the authority to manage and improve the potential of each region optimally. The village autonomy also enables each village to have its control over its territory even if it not separated from the supervision of the regional and central government, in order for it not to be misused. The utilization of the village potential actualized into what is known as village-owned enterprises (Putterman 1997, Prabowo 2014, Hidayati 2015, Sudaryana 2016, Huruta \& Sasongko 2016). The presence of Law Number 8 of 2005 concerning 
amendments to Law Number 32 of 2004 indicates that the village government has the right to establish village-owned enterprises following the needs and potential of the village. The Ponggok Village government established the village-owned enterprises on December $15^{\text {th }}, 2009$, and it was called Tirta Mandiri village-owned enterprises. At the beginning of the Tirta Mandiri village-owned enterprises, they first developed a business unit called Umbul Ponggok. In line with the development and increasing number of revenue generated by the village-owned enterprises, and it went on to develop several business units.

Nowadays, Tirta Mandiri village-owned enterprises involve various business units as well as more business units that are in progress. The Ponggok Village government develops social activities, capital assistance, entrepreneurship training, and the establishment of village economic institutions, namely Tirta Mandiri. The village-owned enterprises are managed based on the local wisdom (Huruta \& Kurniasari 2018) that is owned by the Ponggok villagers. The villagers run the village-owned enterprises together with the government. In order to reinforce the joint committee, the Tirta Mandiri village-owned enterprises have interpreted their spirit into a logo. The formation of Tirta Mandiri village-owned enterprises believed to have stimulated and driven the economy in rural areas. The village assets are managed entirely by the villagers. In practice, the institution of the village-owned enterprises imbued with the spirit of togetherness as an effort to strengthen the identity.

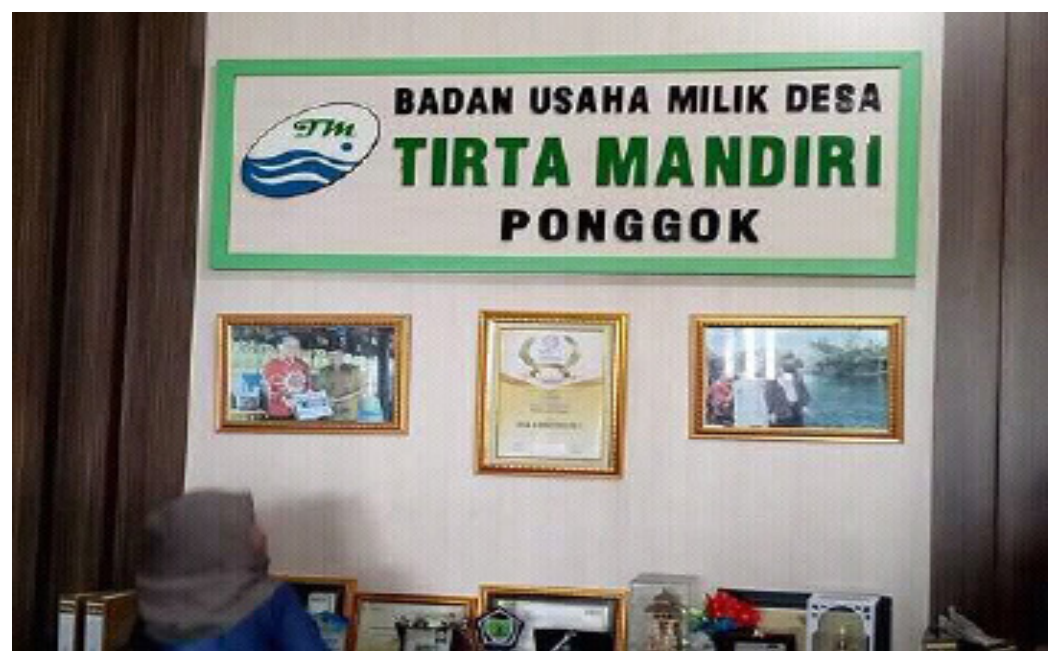

Figure 1.

Tirta Mandiri village-owned enterprises

Source: Personal Documentation (2018)

In China, Putterman (1997) explained the historical success of the industrial enterprises owned by the township and village governments. The peculiar conditions within China's economy have fostered the growth of a skilled workforce and high savings, creating unusual market niches and encouraging entrepreneurial undertakings by the local political elites, especially in areas adjacent to certain cities. In Indonesia, the presence of village-owned enterprises has had a positive impact on the economy of rural communities. The implementation of the policy on the management of village-owned enterprises, human resource managers, and the participation of the private sector and government in the capital relates to mentoring as well as how much benefit to provides concerning the welfare of the rural communities (Sudaryana 2016 \& Prabowo 2014). Furthermore, Anggraeni (2016) and Dewi (2014) found that through the existence of the village-owned enterprises, the community can manage the potential of the village and make it into a source of income for both the village and the community. Another advantage of the existence of the village-owned enterprises is that it is a place that can accommodate every economic activity. It has become a public service institution for the village community (Sihabudin 2009, Zulkarnaen 2016, \& Hardijono et al. 2014). Hayyuna et al. (2014) and Hidayati (2015) showed that an increase in the village's original income could be generated through the structured and systematic management of the village-owned enterprises. However, Syahril et al. (2019) stated there are constraining factors affecting the financial performance of the villageowned enterprises, namely capital, responsibility, public education, and beliefs, as well as the type of businesses involved. 
Furthermore, Huruta and Sasongko (2016) explained that due to the existence of the village-owned enterprises, the community would be more helpful. However, as there is still a lack of certain guarantees for the community, the need for legal protection in the form of village regulations regarding the village-owned enterprises provides a more secure guarantee for every community. Since they first established, the village-owned enterprises have served as a tool to increase the village's original income and the community income as well. The village-owned enterprises are also able to create new business opportunities that can be utilized by the community. The village-owned enterprises are one of the institutions in the village that are engaged in both business and economic empowerment. Tirta Mandiri village-owned enterprises also act as a supporter of the processes involved in the development of Ponggok Village. The focus of this study emphasizes the role of the village-owned enterprises in creating new business fields in Ponggok Village.

\section{Research Method}

The approach used in this article was qualitative, executed in the form of a case study (Yin 2002). The primary consideration related to choosing Ponggok Village as the object of the research was that Ponggok Village had a village-owned enterprises that was different from the other villageowned enterprises throughout Indonesia. These village-owned enterprises, which have become the spotlight at the national, regional, and local level, is collectively made up of Tirta Mandiri villageowned enterprises. The village-owned enterprises have a business unit in the form of seven Limited Companies (Ltd.). Based on the business units developed, they have been able to create new business fields for the community.

Furthermore, the type of data used in this article was the primary data - the data collected through observations and interviews with both critical informants and supporting informants. The key informants were seven new business field owners as well as two supporting informants, namely the managers of Umbul Ponggok Ltd. and Tirta Mandiri Ltd. In addition to the primary data, secondary data also collected through the business management and planning documents of Tirta Mandiri village-owned enterprises. The analysis technique used in this study was inductive. This technique emphasizes the understanding of reality and then determines the frame of the theory and the findings that are relevant to the role of the village-owned enterprises in creating new jobs.

\section{Results and Discussion}

\section{"Participation" as the foundation for the development of the village-owned enterprises}

The village-owned enterprises' activities are an economic driving force in Ponggok Village that has attracted many of Ponggok's residents. In the beginning, only part of the community joined the Ponggok village-owned enterprises. However, as more time went by, and as the village-owned enterprises grew, more people took advantage of the initiative to participate in the village-owned enterprises (Prabowo 2014 \& Hardijono et al. 2014). In relation to this fact, AG said:

"The Ponggok people who contribute to the development of village-owned enterprises feel
happy. It happened because the village-owned enterprises provides real benefits for the
community. People who work in the village-owned enterprises business units are given
a BPJS Ketenagakerjaan (a National Social Security Administrative Organization covering
employment insurance) card. In addition, they also get a card from BPJS Kesehatan (a
National Social Security Administrative Organization covering health insurance)."

From what was illustrated by AG above, there is an effort made by the village-owned enterprises, so then the community can participate in the village-owned enterprises' activities (Prabowo 2014). The village-owned enterprises also provides tangible benefits to the community, so then they feel comfortable and trust the village-owned enterprises. In line with AG's statement, S said:

"Ponggok people who want to work in the village-owned enterprises can register themselves directly to the Tirta Mandiri village-owned enterprises. Tirta Mandiri village-owned enterprises 
accepts people who want to work without considering their educational background. The village-owned enterprises also provides education and training for the community."

Based on S's explanation, it has been illustrated that the Tirta Mandiri village-owned enterprises has directly opened up opportunities for everyone to contribute to the village-owned enterprises. In addition, the village-owned enterprises also provide training for those who want to contribute to the village-owned enterprises (Hardijono et al. 2014). In other words, the village-owned enterprises can create a more competitive society in the business world. In line with AG and S, SB also mentioned:

\footnotetext{
"The presence of Tirta Mandiri village-owned enterprises helps the poor. Even those who have not contributed to the village-owned enterprises get a positive impact. They get assistance in the form of 200,000 IDR per month, widows get 200,000 IDR per month, and students get 300,000 per month. The village-owned enterprises also gives cash for village development to every neighborhood unit $(R W)$."
}

Based on SB's explanation, it has been illustrated that the village-owned enterprises plays an essential role in the welfare of the community. The village-owned enterprises is also able to assist the underprivileged communities, making the village-owned enterprises increasingly trusted by the community as a whole. They are thus able to become a foundation for improving people's living standards (Sudaryana 2016 \& Prabowo 2014).

\section{"Social Capital" as the community's energy}

The development of Tirta Mandiri village-owned enterprises supported by the enthusiasm of the local community in Ponggok Village. Attitude refers to the assessment of each individual and whether they are relatively defensive about the principles they hold or not (Putterman 1997 \& Djumaty 2015). Thanks to the energetic principles of the Ponggok community itself and the influential local culture, they can increase their economy through the village-owned enterprises. It strengthened by the statement given by $\mathrm{S}$ who mentioned:

"Within a week, there will be meetings with the community members to discuss the development of the village-owned enterprises. I feel that working in the village-owned enterprises is a source of pride. I work not only for my own sake but for all of the residents in Ponggok Village."

S's explanation illustrates that the Ponggok community is in a state of mental readiness. It is in line with the view of Meinarno and Sarwono (2017), who stated that a process that takes place within each society that allows them to direct and determine the response to each object and the situation that they face. Therefore, the success of Tirta Mandiri village-owned enterprises can make people better aware of the importance of village development based on the presence of social capital.

\section{"Stock" as a bridge to community trust in the village-owned enterprises}

Nowadays, a person's motive for holding money is not only to use it for transactions but also for speculation and as a way of taking precautions (Keynes 1936). Similarly, Ponggok Village uses funds from the community to run the business unit activities. Concerning financial matters, Kabalmay (2008) mentioned that money is the most concrete tool used for realizing the village autonomy and improving community welfare. It indicates that autonomy without money is 'nonsense.' It happens because money is needed to build a village. Money is energy, and planning is the compass. At the other side, authority was a position for the village to recognize its sovereignty in full charge (Huruta \& Sasongko 2016).

Since its establishment, Tirta Mandiri village-owned enterprises have provided village financial resources originating from all communities. A large percentage of these are a source of village-owned enterprises development. Up until 2017, the revenue of Tirta Mandiri village-owned enterprises reached 13,000,000,000 IDR. This achievement is inseparable from the stock investment given by 
the community to the village-owned enterprises. It provides excellent benefits when it comes to developing the village. The money invested by the community will be returned to the community with satisfactory results. In addition, village-owned enterprises' income used as a means of developing other business units that have been planned for development.

The current programs run by Tirta Mandiri village-owned enterprises could increase the income of both the village and the villagers. Kabalmay (2008) said that the efforts undertaken to increase the source of the village income had been regulated in Law No. 32 of 2004 Article 213 Paragraph 1, which states that "The village can establish a village-owned enterprises following the needs of the village." Furthermore, this was strengthened by Government Regulation No. 72 of 2005 Article 78-81 on the concept of village-owned enterprises that can be developed by the village, whose management carried out in a participatory, democratic, transparent, and emancipatory manner.

Tirta Mandiri village-owned enterprises require every family to invest their money in the villageowned enterprises as a way of sourcing the capital for the village-owned enterprises' business unit development. Investment has become the energy necessary in the village-owned enterprises to make development happen. The number of shares offered to the public start from 100,000 IDR and went up to 5,000,000 IDR per family. The following documents are the sample specimens offered by the Tirta Mandiri village-owned enterprises to the community, as can be seen in Figures 2 and 3.

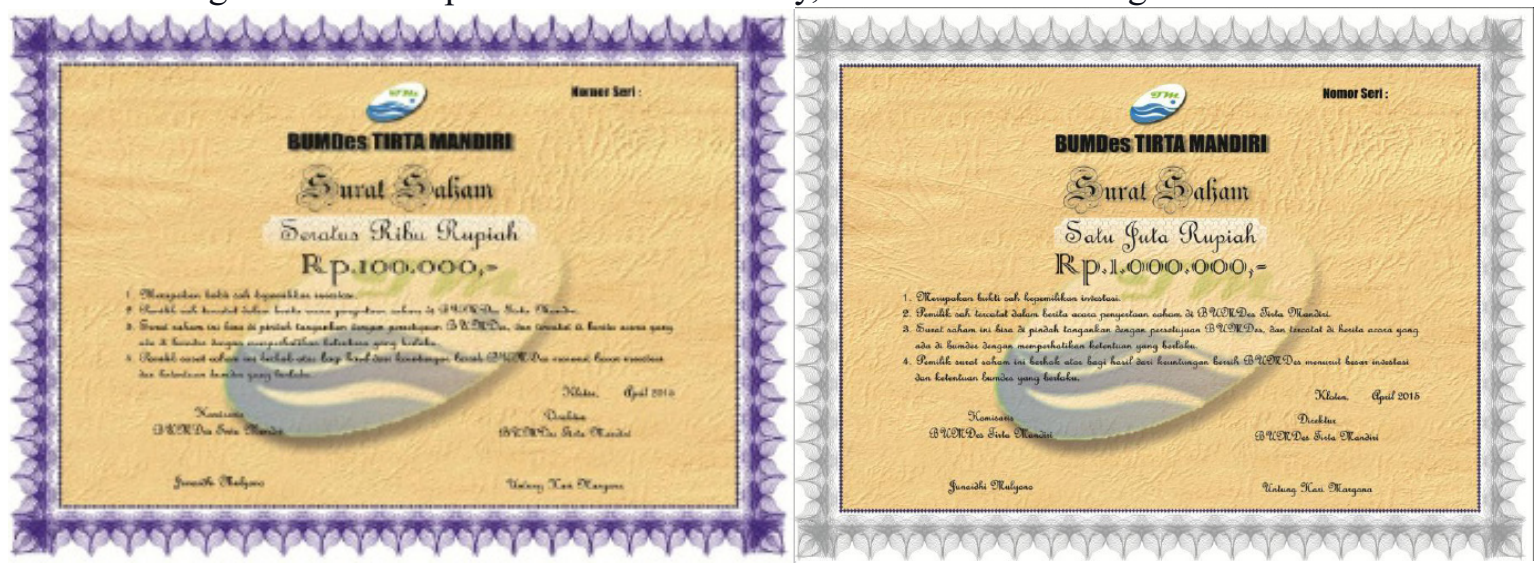

Figure 2.

Share Sheet Specimen for 100,000 IDR and 1,000,000 IDR

Source: Personal Documentation (2018)

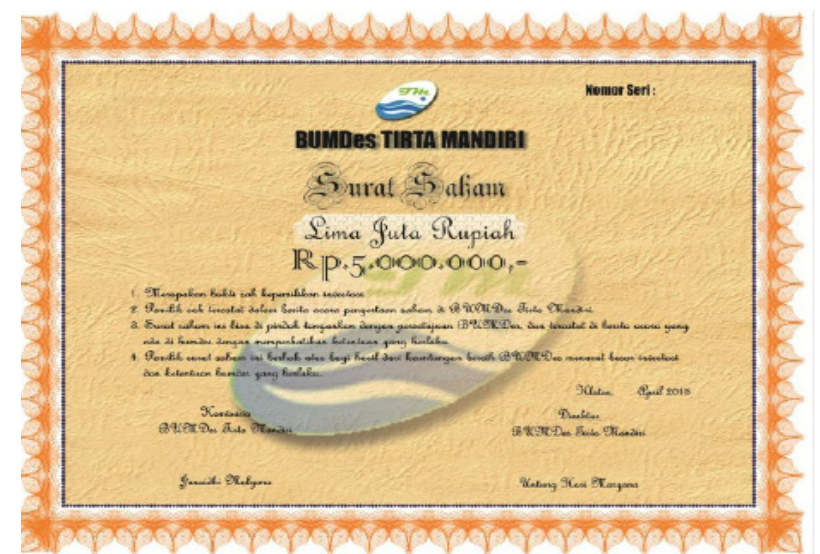

Figure 3.

Share Sheet Specimen for 5,000,000 IDR

Source: Personal Documentation (2018)

In relation to the documentation above, $\mathrm{N}$ mentioned:

"Nearly $70 \%$ of the Ponggok community invest in the village-owned enterprises. In 2018, it targeted that all Ponggok residents will participate in the shares. For people who cannot afford to invest, they will be given loans from the village-owned enterprises business units." 
Based on $\mathrm{N}$ explanation, it has been illustrated that the existence of investment in the village-owned enterprises can increase and accelerate the construction of business units in the village-owned enterprises. The results show that the village-owned enterprises can be enjoyed by every citizen in Ponggok Village. This is in line with the findings of Todaro and Smith (2015) who stated money from the community itself is very important. It indicates that the capital from the community plays an essential role in influencing the economic life of a nation. This happens because the formation of capital increases the production capacity, thus increasing the villager's income and creating new jobs. Seeing the opportunity to invest, AG said:

"The results of the investment in Tirta Mandiri village-owned enterprises have provided tangible benefits. If there are only a few visitors, then the distribution of the results reaches 300,000 IDR to 400,000 IDR per month. If there are many visitors, then it can reach 500,000 IDR to 600,000 per month."

AG's explanation illustrates that investment is the energy involved in the formation of village-owned enterprises, so then the village-owned enterprises can run as an economical wheel in the village and complete all of the planned programs. The investment results can increase the residents' income, thus enabling the needs of the community to be fulfilled. Investment is a bridge between the public's trust and village-owned enterprises when it comes to providing feedback to the community, such as creating jobs and new business fields (Prabowo 2014). This condition supported by the findings of Putterman (1997), who argued that the skills of the workforce and high savings create unusual market niches and encourage entrepreneurial undertakings by the local political elites.

\section{Generating advantages from cheap stalls}

From the various productive business activities controlled by the Tirta Mandiri village-owned enterprises, many people are starting to see new opportunities to get an income from the business units through the village-owned enterprises. It is used by the community to increase their income to fulfill their needs. This strategy did not arise through planning. It occurs because of a situation that forces them to do something (Boari 2014). For example, SB took advantage of Artha Tirta Ponggok Ltd.'s activities by borrowing money to start her business. Concerning this fact, SB mentioned:

"I got the initial capital to start the food stall through a loan from the village-owned enterprises business unit. The village-owned enterprises also rent out stalls at low prices for 3,000 IDR per day, and it is usually paid every week, while the electricity and clean water costs are paid jointly. The gross profits reach 400,000 IDR to 1,000,000 per day."

SB's description illustrates that numerous opportunities can be obtained from the village-owned enterprises. Recently, there have been many people who have finally experienced the multiplying effect of the village-owned enterprises business unit. This condition supported by the findings of Putterman (1997), Sudaryana (2016), Prabowo (2014), and Dewi (2014), who mentioned that villageowned enterprises is very beneficial for the development of the village. In the effort to achieve prosperity, it requires the management of the village potential that is transparent and accountable.

\section{Fighting between opportunities}

Village-owned enterprises has had a significant influence on people's welfare directly. SS was able to get an additional income to fulfill her needs when she started the clothing store business. In relation to this fact, SS mentioned:

"Village-owned enterprises business unit can help me meet my life needs. I have experience of about one year. The village-owned enterprises provides the place to sell that is also very strategic, and the rental price is quite cheap."

SS's explanation illustrates that the Umbul Ponggok Ltd. business unit has been beneficial concerning the community. SS could run a business such as selling swimwear. In addition, various food stalls 
and street vendors have appeared around the village-owned enterprises. This finding supported by the findings of Prabowo (2014), Anggraeni (2016), and Sudaryana (2016), who mentioned that the village-owned enterprises could significantly influence the social economy of the village directly. Communities can experience the impact of government programs, or they can plan to improve and increase the village economy. It indicates that the village-owned enterprises can create opportunities for the community to improve their standard of living (Hayyuna et al. 2014 \& Hidayati 2015).

\section{From an opportunity to profit}

Nowadays, many business opportunities can be utilized by the local people. The presence of Tirta Mandiri village-owned enterprises has prompted the community to start opening grocery stalls. Sumber Panguripan Ltd. supplies the items in the stalls. The role of the village-owned enterprises in Ponggok Village is very important because many people earn their income from the existence of the village-owned enterprises. The community can get an additional income that can be used to fulfill their needs (Prabowo 2014). It confirmed by AH who stated that:

"This business was formed due to activities in the Sumber Panguripan store. I started this stall two years ago. With the help offered by the Sumber Panguripan store, it made it easy for me to buy the groceries that I will sell. Other people that start similar businesses feel that they are being helped a lot."

AH's explanation illustrates that the presence of the village-owned enterprises has a very positive impact in and on the community. Many people have taken advantage of the village-owned enterprises. It supported by the findings of Prabowo (2014), Anggraeni (2016), and Sudaryana (2016), who have mentioned that the existence of the village-owned enterprises has brought in significant changes to the economic and social fields.

\section{Generating a profit from ice cubes}

Air Ponggok Ltd. was one of the business units developed by the village-owned enterprises that manufacturing mineral water. This business unit is a source of income. One of the benefits that emerged from the existence of this particular business unit was the emergence of a new business, namely an ice cube factory. Many business opportunities have been made successful due to the existence of the village-owned enterprises business units, and due to the village-owned enterprises' collaboration with the community (Prabowo 2014). It supported by the view of AM who mentioned that:

"I see that there are a lot of food and beverage businesses around the village-owned enterprises. Therefore, I can distribute ice cubes to the food and beverage businesses near to the villageowned enterprises. In addition, the place to take the mineral water is near to my place, and it can also be delivered to my house."

AM's explanation illustrates that the village-owned enterprises business units are very helpful when it comes to providing opportunities for the community to start other businesses. It supported by the findings of Anggraeni (2016), Dewi (2014), Hidayati (2015), and Hayyuna et al. (2014), who stated that the presence of village-owned enterprises helps the community to manage the village potential as a source of income.

\section{Fish food stalls as an income source}

The presence of the village-owned enterprises in the village is very important. Village-owned enterprises can guarantee the welfare of the community (Sudaryana 2016 \& Prabowo 2014). Tirta Mandiri village-owned enterprises can assist the food stall owners in Ponggok Village by supplying tilapia fishes farmed by Mina Tirta Ltd. Based on this fact, $\mathrm{N}$ mentioned:

"I take advantage of this opportunity by selling food using the tilapia menu. I did this to introduce visitors to the idea that Ponggok is a tilapia producer. The raw materials are very easily accessible in the business units of Mina Tirta Mulia village-owned enterprises, which provide fresh tilapia and other types of fish.” 
N's narrative illustrates that there are many opportunities to create new businesses. The presence of new businesses further introduces the local traditions and culture of Ponggok Village to the outside community. This is supported by the findings of Prabowo (2014), Dewi (2014), and Sudaryana (2016) who mentioned that village-owned enterprises are able to increase the productivity of rural communities. Village-owned enterprises also provide more opportunities for the community to start other businesses. Therefore, where the village-owned enterprises can increase the productivity of the community, the resident's income will also increase (Hayyuna et al. 2014 \& Hidayati 2015).

\section{Generating profits from paper and ink}

Village-owned enterprises strongly supported village development. It because of the initiative of the community to build a village-owned enterprises together. The community participated directly in all village-owned enterprises activities, so then the village-owned enterprises run according to the plan. Their spirit proven by the presence of the Zaura photograph business. This business entity has emerged as a result of the cooperation between the Tirta Mandiri village-owned enterprises and the community. Concerning this fact, RR mentioned:

"I feel very much helped by the existence of these village-owned enterprises. Tirta Mandiri village-owned enterprises has triggered an increase in Ponggok Village's income and the income of the people who have participated in the Tirta Mandiri village-owned enterprises."

RR's narrative illustrates that the village-owned enterprises has played an important role in improving the village economy (Anggraeni 2016 \& Dewi 2014). The village-owned enterprises can contribute to society through the business units that have been developed. It supported by the findings of Prabowo (2014) and Sudaryana (2016), who mentioned that village-owned enterprises has a positive impact in terms of improving the economy of the community. In other words, the village-owned enterprises supports the village economy. It indicates that everyone has the same opportunity to generate a profit through the existence of the village-owned enterprises (Hayyuna et al. 2014 \& Hidayati 2015).

\section{Starting from willingness and confidence}

The presence of the Tirta Mandiri village-owned enterprises had a positive impact on the economy of the Ponggok Village community. It evidenced by the increasingly even village development encouraged by the funds generated by the village-owned enterprises. It the main driver for PB to make a homestay business. This opportunity emerged because of a large number of visitors who came to visit Umbul Ciblon and other tourist destinations in Ponggok Village. Related to this, PB also mentioned:

"I have built a homestay business for approximately three years. I started this business because many visitors come to Ponggok tourism places. I saw many visitors from outside the city, so I tried to make a homestay here. There are still many tourists who are looking for a homestay. During the holiday season, many visitors want to spend a night in Ponggok village."

According to $\mathrm{PB}$, there are many opportunities provided by the existence of the Tirta Mandiri village-owned enterprises. These opportunities utilized by starting small to large-scale businesses. It done by having the willingness and confidence to develop opportunities (Hardijono et al. 2014). In other words, the village-owned enterprises not only increases the village's original income and the overall community income but also create new businesses and help the village to progress in a better direction (Prabowo 2014). It supported by the findings of Hardijono et al. (2014), Sihabudin (2009), and Zulkarnaen (2016), who mentioned that the purpose of the village-owned enterprises is to improve the village economy based on their needs and potential. It also confirmed by the findings of Prabowo (2014), Sudaryana (2016), Hidayati (2015), and Hayyuna et al. (2014), who mentioned that the existence of the village-owned enterprises means that the prosperity of the community in the village will become more secure. It happens because the village development can be increasingly targeted because of the funds generated by the village-owned enterprises. 


\section{Conclusion}

All of the village-owned enterprises business units that developed have proven to be able to improve the economy of the community. The presence of the village-owned enterprises can create businesses such as 1) SB's stall built because of Artha Tirta Ponggok Ltd., 2) Ponggok clothing store built because of Umbul Ponggok Ltd., 3) grocery stalls built because of Sumber Panguripan Ltd., 4) an ice cube factory-built because of Air Ponggok Ltd., 5) Tilapia fish food stalls built because of Mina Tirta Ltd., 6) Zaura Photograph which built because of Panguripan Ltd., and 7) Pandu Homestay built because of Umbul Ciblon Ltd.

Social capital needed from within the community as a foundation for the development of a new unit within the village-owned enterprises. This evidenced by the community's participation through investment, which is also a sign of the trust given by the community. It is a source of energy in the development of the village-owned enterprises. Regarding the prospects of the Tirta Mandiri villageowned enterprises, the development and formation of village-owned enterprises business units reduce the unemployment rate in Ponggok village. It happens because of the high level of interest among the people who want to participate in both creating business fields and working in the Tirta Mandiri village-owned enterprises. Therefore, Tirta Mandiri village-owned enterprises need to develop or create new business units that can employ more workers. One of the concrete actions taken was the business expansion of Sumber Panguripan Ltd. In addition, upon seeing the potential of the tilapia fish farms in Ponggok Village, there needs to be a tilapia fish processing factory. The development or manufacturing of new business units believed to be able to create new opportunities that can be utilized by the community as a business opportunity.

In general, several factors are obstacles to the development of Tirta Mandiri village-owned enterprises. These factors include a low level of community education and a low amount of effort being put in when it comes to collaborating with other villages that are close to Ponggok Village. Social capital is a strategy that can be used to develop sustainable Tirta Mandiri village-owned enterprises. The indicators of social capital include trust, norms, and networks. Trust shown by the presence of honest, orderly, and cooperative behavior. The norms demonstrated through the understanding, values, and hopes that are believed in and carried out collectively by the Ponggok villagers. Networks shown through communication, relationships, and interactions (e.g., with the Ponggok villagers and in the surrounding villages).

\section{References}

AG (2018) [Personal communication] 07 March.

AH (2018) [Personal communication] 05 May.

AM (2018) [Personal communication] 06 May.

Anggraeni MRRS (2016) Peranan Badan Usaha Milik Desa (BUMDes) pada kesejahteraan masyarakat pedesaan studi pada BUMDes di Gunung Kidul, Yogyakarta. Jurnal MODUS 28 (2):155-167. [Accessed 2 October 2018]. https://doi.org/10.24002/modus.v28i2.848.

Boari Y (2014) Berjuang di antara Peluang (Studi pada Pedagang Mama-Mama Asli Papua di Pasar Remu Kota Sorong). Salatiga: Satya Wacana University Press.

Dewi ASK (2014) Peranan Badan Usaha Milik Desa (BUMDes) sebagai upaya dalam meningkatakan pendapatan asli desa (PADes) serta menumbuhkan perekonomian desa. Journal Rural and Development 5 (1):1-3. [Accessed 4 October 2018]. https://jurnal.uns.ac.id/rural-anddevelopment/article/view/914.

Djumaty BL (2015) Persepsi, Sikap, dan Partisipasi (Masyarakat Desa Idamdehe, Kab. Halbar Terhadap Rencana Pembangunan PLTP. Salatiga: Satya Wacana Univesity Press.

Hardijono R, Maryunani, Yustika AE, \& Ananda CF (2014) Economic independence of the Village Through Institutional Village Enterprises (BUMDes). Journal Economics and Finance (IOSR-JEF) 3 (2):21-30. [Accessed 6 October 2018]. https://www.iosrjournals.org/iosr-jef/ papers/vol3-issue2/Version-3/D03232130.pdf. 
Hayyuna R, Pratiwi RN, \& Mindarti LI (2014) Strategi manajemen aset BUMDes dalam rangka meningkatkan pendapatan desa (Studi pada BUMDES di Desa Sekapuk, Kecamatan Ujung Pangkah, Kabupaten Gresik). Jurnal Administrasi Publik 2 (1):1-5. [Accessed 7 October 2018]. https://media.neliti.com/media/publications/76716-ID-strategi-manajemen-aset-bum des-dalam-ran.pdf.

Hidayati U (2015) Performance analysis of village-owned enterprises managers as a basic of designing education and training. European Journal of Business and Management 7 (32):143-147. [Accessed 11 October 2018]. https://pdfs.semanticscholar.org/e74b/db99666ca334a150e976 23ebd8eb3ae400c9.pdf.

Huruta AD \& Kurniasari MD (2018) Environmental management within the indigenous perspective. Masyarakat, Kebudayaan dan Politik 31 (3):270-277. [Accessed 11 October 2018]. http:// doi.org/10.20473/mkp.V31I32018.270-277.

Huruta AD \& Sasongko G (2016) Uang dan ruang yang berkelanjutan dalam pembentukan Badan Usaha Milik Desa (BUMDes). Masyarakat, Kebudayaan dan Politik 29 (4):212-222. [Accessed 11 October 2018]. http://doi.org/10.20473/mkp.V29I42016.212-222.

Kabalmay RR (2008) Uang dan Ruang untuk Membangun Ekonomi Desa. Yogyakarta: Forum Pengembang Pembaharuan Desa.

Keynes JM (1936) The General Theory of Employment, Interest, and Money. United Kingdom: MacMillan and Cambridge University Press.

Meinarno EA \& Sarwono SW (ed) (2017) Psikologi Sosial. Jakarta: Salemba Humanika.

N (2018) [Personal communication] 06 May.

PB (2018) [Personal communication] 10 May.

Prabowo THE (2014) Developing BUMDes (village-owned enterprises) for sustainable poverty alleviation model (village community study in Bleberan-Gunung Kidul-Indonesia). World Applied Sciences Journal 30:19-26. [Accessed 9 October 2018]. https://www.idosi.org/wasj/ wasj30(icmrp)14/4.pdf.

Putterman L (1997) On the past and future of China's Township and village-owned enterprises. World Development 25 (10):1639-1655. [Accessed 11 October 2018]. https://doi.org/10.1016/S03 05-750X(97)00060-0.

RR (2018) [Personal communication] 07 May.

S (218) [Personal communication] 07 May.

SB (2018) [Personal communication] 12 March.

Sihabudin (2009) Legal entity form of village-owned enterprises (BUMDes) potential-based village economy. Journal of Social Sciences 21 (1):33-41.

SS (2018) [Personal communication] 05 Mei.

Sudaryana B (2016) The model of development policy implementation of village owned enterprises in Indonesia. In: 1st International Conference on Social and Political Development (ICOSOP 2016) 81. Medan: Atlantis Press, 23-29. [Accessed 8 October 2018]. https://doi.org/10.2991/ icosop-16.2017.3.

Syahril, Ghufron AFA, \& Herli M (2019) Factors affecting financial performance of village-owned enterprises: A case study in the District of Rock Sumenep. International Journal of Business and Commerce 7 (2):1-9. [Accessed 1 October 2018]. https://www.ijbcnet.com/7-2/IJBC18-7108.pdf.

Todaro MP \& Smith SC (2015) Economic Development. 12 ${ }^{\text {th }}$ edition. Washington DC: Pearson.

Yin RK (2002) Studi Kasus: Desain dan Metode. Jakarta: Raja Grafindo Persada.

Zulkarnaen RM (2016) Pengembangan potensi ekonomi desa melalui Badan Usaha Milik Desa Pondok Salam Kabupaten Purwakarta Bandung. Jurnal Aplikasi Ipteks untuk Masyarakat 5 (1):1-4. [Accessed 3 October 2018]. http://jurnal.unpad.ac.id/dharmakarya/article/ view/11430. 